DOI: https://doi.org/10.24843/JFU.2019.v08.i01.p08

pISSN: 2301-7716; eISSN: 2622-4607

Jurnal Farmasi Udayana, Vol 8, No 1, Tahun 2019, 50-58

\title{
Efek Penggunaan Obat Antidiabetes terhadap Luaran Terapi Pasien Diabetes Melitus Tipe 2 Komplikasi Retinopati Diabetik di RSUP Sanglah Denpasar
}

\author{
Sukarmini, N. N. F. ${ }^{1}$, Samba, N. M. R. A. M. ${ }^{1}$, Lestari, N. K. S. ${ }^{1}$, Sarasmita, M. A. ${ }^{1}$, Larasanty, L. P. F. ${ }^{1}$ \\ ${ }^{1}$ Program Studi Farmasi Fakultas Maematika dan Ilmu Pengetahuan Alam Universitas Udayana, Bukit Jimbaran, \\ Badung, 80361 \\ E-mail:nyomanfabby@gmail.com
}

\begin{abstract}
ABSTRAK
Retinopati diabetik (RD) merupakan komplikasi mikrovaskular DM karena adanya kerusakan pembuluh darah retina yang dapat menyebabkan kebutaan permanen. Kontrol glukosa darah yang baik terbukti mengurangi onset dan risiko perkembangan $\mathrm{RD}$. penelitian ini bertujuan untuk mengetahui penggunaan obat antidiabetes pada pasien DM tipe 2 komplikasi RD dan luaran terapi dilihat dari perubahan kadar glukosa darah dan derajat RD pasien. Desain penelitian ini adalah observasional dengan pendekatan retrospektif. Data penelitian diperoleh dari rekam medis pasien DM tipe 2 komplikasi RD periode Januari 2018-Desember 2018 di RSUP Sanglah. Data derajat RD dianalisis secara deskriptif sedangkan perubahan kadar glukosa darah dianalisis secara statisik (paired t-test dan wilcoxon). Pada penelitian ini didapatkan sebanyak 29 pasien yang memenuhi kriteria inklusi dengan penggunaan obat terdiri dari insulin sebanyak 14 pasien (48,3\%), OAD (oral antidiabtes drugs) sebanyak 9 pasien $(31,0 \%)$ dan kombinasi OAD + insulin 6 pasien $(20,7 \%)$. Rata-rata KGDP pasien menurun signifikan $(p<0,05)$ pada penggunaan $\mathrm{OAD}$, insulin, dan kombinasi $\mathrm{OAD}+$ insulin masing-masing sebesar 52,22 $\pm 20,34$; $58,86 \pm 19,29$ dan $92,83 \pm 26,99 \mathrm{mg} / \mathrm{dL}$. Rata-rata KGD2PP pasien menurun signifikan $(\mathrm{p}<0,05)$ pada

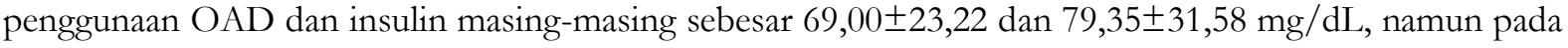
penggunaan kombinasi $\mathrm{OAD}+$ insulin penurunan yang terjadi tidak signifikan $(\mathrm{p}>0,05)$ sebesar $67,33 \pm 49,55 \mathrm{mg} / \mathrm{dL}$. Rata-rata HbA1c pasien menurun signifikan $(\mathrm{p}<0,05)$ pada penggunaan $\mathrm{OAD}$, insulin dan kombinasi $\mathrm{OAD}+$ insulin masing-masing sebesar $1,77 \pm 0,39 ; 1,58 \pm 0,52$ dan $1,60 \pm 0,55 \%$. Peningkatan derajat RD terjadi pada 5 dari $29(17,24 \%)$ pasien.
\end{abstract}

Kata kunci: Dabetes mellitus tipe 2, Retinopati diabetik, Glukosa darah, OAD, Insulin.

\section{ABSTRACT}

Diabetic retinopathy (DR) is a microvascular complication of DM caused by damage to blood vessels in the retina and can cause permanent blindness. Good blood glucose control has been shown to reduce DR onset and risk of development. The purpose of this study was to determine the use of antidiabetic drugs in patients with DM type 2 complication DR and outcomes therapy seen from changes in blood glucose levels and degrees of DR. The design of this study was observational with retrospective data collection obtained from the medical record of patients type 2 DM complication DR from January 2018 to December 2018 in Sanglah General Hospital. Characteristic of patient and DR degrees were analyzed descriptively while changes in blood glucose levels for 6 months were analyzed with statistic (paired t-test and Wilcoxon). In this study, 29 patients were included consisted of 14 patients (48.3\%) used insulin, 9 patients used $O A D(31.0 \%)$ and 6 patients used combination $O A D+$ insulin $(20.7 \%)$. The mean KGDP of patients decreased significantly $(p<0.05)$ in the $O A D$,

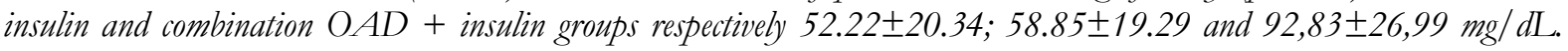
The mean KGD2PP of patients decreased significantly $(p<0.05)$ in the $O A D$ and insulin groups respectively $69.00 \pm 23.22$ and $79.35 \pm 31,58 \mathrm{mg} / \mathrm{dL}$, but in the combination $\mathrm{O} A D+$ insulin group, reduction that occurred was not

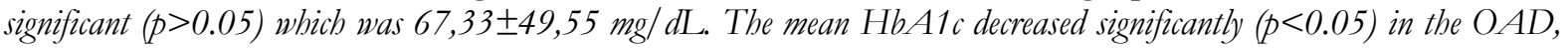
insulin and combinations $O A D+$ insulin group respectively by $1.77 \pm 0.39,1.58 \pm 0.52$ and $1.60 \pm 0,55 \%$. Increased degree of $R D$ occurs in 5 of $29(17.24 \%$.)

Keywords: Type 2 diabetes mellitus, Diabetic retinopathy, Blood glucose, OAD, Insulin. 
DOI: https://doi.org/10.24843/JFU.2019.v08.i01.p08

pISSN: 2301-7716; eISSN: 2622-4607

Jurnal Farmasi Udayana, Vol 8, No 1, Tahun 2019, 50-58

\section{PENDAHULUAN}

Diabetes melitus (DM) merupakan kondisi hiperglikemia yang disebabkan oleh kelainan kerja insulin, sekresi insulin atau keduanya (PERKENI, 2015). Menurut $W$ old Health Organization (2016), secara global pada tahun 2014 DM meneyebabkan kematian secara langsung sekitar 1,5 juta jiwa dan jumlah penderita DM pada tahun 2014 sebesar 422 juta jiwa. Penderita diabetes melitus di Indonesia pada tahun 2000 mencapai 8,4 juta jiwa dan diprediksi jumlahnya akan meningkat menjadi sekitar 21,3 juta jiwa di tahun 2030 (PERKENI, 2015). Kejadian DM tipe 2 di Indonesia memiliki prevalensi yang lebih tinggi di bandingkan DM tipe 1 (Soegondo, 2008).

Retinopati diabetik (RD) merupakan komplikasi mikrovaskular DM karena adanya kerusakan pembuluh darah retina yang dapat menyebabkan kebutaan permanen (Kementrian Kesehatan RI, 2014). Pasien DM yang menderita RD secara global mencapai 93 juta orang dan sebanyak 28 juta orang memiliki risiko mengalami kebutaan karena RD (Yau et al., 2012). Menurut Diabcare Asia tahun 2008, dari 1785 pasien DM tipe 2 di pusat pelayanan primer dan sekunder di Indonesia, sebesar 42\% menderita RD (Nasution, 2011). Peningkatan kejadian DM diperkirakan akan dibarengi dengan peningkatan kejadian RD (Lee et al., 2015)

Retinopati diabetik sebagai salah satu komplikasi dari DM harus diwaspadai karena dapat menimbulkan kebutaan yang menurunkan kualitas hidup dan produktivitas pasien. Komplikasi RD pada pasien DM tipe 2 menimbulkan dampak lebih lanjut berupa peningkatan biaya kesehatan pada pasien dan menimbulkan beban sosial di masyarakat (Sitompul, 2011). Kondisi hiperglikemi kronik dapat menyebabkan perubahan histopatologi pada pembuluh darah retina yang dapat menyebabkan $\mathrm{RD}$ berkembang ke derajat yang lebih parah (Lee et al., 2015).
Progresivitas RD sebagai penyulit DM dapat dilihat melalui derajat keparahan RD yang dapat meningkat dari derajat NPDR (NonProliferative Diabetic Retinopathy) ke derajat yang lebih parah yaitu PDR (Proliferative Diabetic Retinopathy) (AAO, 2014).

Kontrol glukosa darah yang baik telah terbukti mengurangi onset dan risiko perkembangan $\mathrm{RD}$ sebesar 31\% (Tschope et al., 2013). Pada studi meta analisis, kontrol glikemik intensif mengurangi risiko kebutuhan tindakan medis untuk penanganan RD seperti fotokoagulasi laser atau vitrektomi (Zhang et al., 2015). Intervensi farmakologis yang dapat diberikan untuk mencapai tujuan tersebut yaitu dengan penggunaan obat antidiabetes meliputi obat antidiabetes oral, insulin, atau kombinasi keduanya (PERKENI, 2015).

Berdasarkan latar belakang di atas, mengingat pentingnya penggunaan obat antidiabetes dalam pencapaian luaran terapi DM khususnya dengan komplikasi RD, maka peneliti tertarik untuk meneliti efek penggunaan obat antidiabetes pada pasien DM tipe 2 untuk melihat luaran terapi dari penggunaan obat antidiabetes yaitu dengan melihat perubahan kadar glukosa darah dan derajat keparahan RD pada pasien DM tipe 2 yang mendapat terapi antidiabetes di RSUP Sanglah Denpasar.

\section{BAHAN DAN METODE}

\section{Bahan dan Alat}

Bahan yang digunakan dalam penelitian ini adalah data rekam medis pasien DM Tipe 2 komplikasi RD. Alat yang digunakan dalam melakukan penelitian ini yaitu lembar pengumpulan data. Lembar pengumpulan data digunakan sebagai tempat menyalin data pada rekam medis pasien (karakteristik pasien, diagnosis, jenis terapi, derajat $\mathrm{RD}$ dan data hasil laboratorium pasien meliputi KGDP, KGD2PP, HbA1c) dan software IBM Statistic SPSS 24 untuk mengevaluasi data secara statistik. 
Sukarmini dkk.

DOI: https://doi.org/10.24843/JFU.2019.v08.i01.p08

pISSN: 2301-7716; eISSN: 2622-4607

Jurnal Farmasi Udayana, Vol 8, No 1, Tahun 2019, 50-58

Metode

Desain penelitian ini adalah

observasional dengan pendekatan

retrospektif. Data penelitian diperoleh dari rekam medis pasien DM tipe 2 komplikasi RD periode Januari 2018 - Desember 2018 di RSUP Sanglah. Pemilihan sampel dilakukan peneliti dengan menelusuri data rekam medis pasien yang memenuhi yang telah ditetapkan peneliti. Kriteria inklusi meliputi pasien DM tipe 2 dengan komplikasi RD yang tercatat pada lembar rekam medis, pasien dengan usia diatas 20 tahun, pasien menerima terapi obat antidiabetes baik terapi antidiabetik oral atau insulin maupun kombinasi keduanya. Kriteria eksklusi meliputi pasien DM dengan kehamilan, pasien yang mendapat terapi antiVEGF dan mendapat tindakan medis untuk penanganan mata seperti fotokoagulasi laser, pasien dengan data rekam medis yang tidak lengkap (data KGDP, KGD2PP, HbA1c dan derajat $\mathrm{RD}$ yang tidak lengkap).

Data pasien yang memenuhi kriteria yang telah ditetapkan, dicatat di lembar pengumpul data. Data yang dicatat meliputi data demografi pasien (umur, jenis kelamin), diagnosa utama (DM tipe 2 dengan $\mathrm{RD}$ ), lama menderita DM, lama menderita RD, obat antidiabetes yang sedang digunakan (jenis/golongan obat, dosis dan frekuensi), derajat keparahan $\mathrm{RD}$, data kadar glukosa darah pasien meliputi kadar glukosa darah puasa (KGDP), Kadar glukosa darah 2 jam post-prandial (KGD2PP), dan HbA1c.

Tahap selanjutnya yang dilakukan setelah data terkumpul yaitu analisis data. Data karakteristik dan derajat RD dianalisis secara deskriptif sedangkan data perubahan kadar glukosa darah dianalisis secara statisik dengan SPSS 24 menggunakan uji statistik paired t-test untuk data yang terdistribusi normal dan uji wilcoxon untuk data yang tidak terdistribusi normal.

\section{HASIL}

Berdasarkan hasil penelitian, diperoleh sebanyak 29 pasien yang memenuhi kriteria inklusi dan ekslusi. Jenis obat antidiabetes yang digunakan di RSUP Sanglah Denpasar pada pasien DM tipe 2 komplikasi RD didominasi oleh insulin yaitu sebayak 14 pasien (48,3\%), selanjutnya OAD sebanyak 9 pasien $(31,0 \%)$ dan kombinasi OAD + insulin sebanyak 6 pasien $(20,7 \%)$.

Tabel 1. Karakteristik Demografi Subjek Penelitian

\begin{tabular}{lcc}
\hline & Jumlah $(\mathbf{n}=\mathbf{2 9})$ & Persentase \\
\hline Jenis Kelamin & & \\
Laki-laki & 18 & $62,1 \%$ \\
Perempuan & 11 & $37,9 \%$ \\
Usia & & \\
$36-45$ tahun & 3 & $10,3 \%$ \\
$46-55$ tahun & 9 & $31,0 \%$ \\
$56-65$ tahun & 11 & $37,9 \%$ \\
$>65$ tahun & 6 & $20,7 \%$ \\
Lama DM & & \\
$<5$ tahun & 2 & $6,9 \%$ \\
$5-10$ tahun & 21 & $72,4 \%$ \\
$>10$ tahun & 6 & $20,7 \%$ \\
\hline
\end{tabular}

Tabe1 2. Perubahan Rata-rata KGDP Pasien DM tipe 2 Komplikasi RD 


\section{Sukarmini dkk.}

DOI: https://doi.org/10.24843/JFU.2019.v08.i01.p08

pISSN: 2301-7716; eISSN: 2622-4607

Jurnal Farmasi Udayana, Vol 8, No 1, Tahun 2019, 50-58

\begin{tabular}{lllcc}
\hline Jenis Obat & $\begin{array}{l}\text { Rata-rata } \\
\text { KGDP Pre } \\
(\mathbf{m g} / \mathbf{d L})\end{array}$ & $\begin{array}{l}\text { Rata-rata KGDP } \\
\text { Post } \mathbf{( m g} / \mathbf{d L})\end{array}$ & Selisih $\mathbf{( m g / d L )}$ & $\mathbf{P}$ \\
\hline OAD & $189,44 \pm 49,46$ & $137,22 \pm 49,31$ & $52,22 \pm 20,34$ & 0,033 \\
Insulin & $184,92 \pm 61,85$ & $126,07 \pm 38,82$ & $58,86 \pm 19,29$ & 0,009 \\
OAD + Insulin & $224,83 \pm 59,88$ & $132,00 \pm 23,62$ & $92,83 \pm 26,99$ & 0,018 \\
\hline
\end{tabular}

Tabe1 3. Perubahan Rata-rata KGD2PP Pasien DM tipe 2 Komplikasi RD

\begin{tabular}{lllcc}
\hline Jenis Obat & $\begin{array}{l}\text { Rata-rata } \\
\text { KGDP Pre } \\
(\mathbf{m g} / \mathbf{d L})\end{array}$ & $\begin{array}{l}\text { Rata-rata } \\
\text { KGDP Post } \\
\mathbf{( m g / d L )}\end{array}$ & $\begin{array}{c}\text { Selisih } \\
\mathbf{( m g} / \mathbf{d L})\end{array}$ & $\mathbf{P}$ \\
\hline OAD & $189,44 \pm 49,46$ & $137,22 \pm 49,31$ & $52,22 \pm 20,34$ & 0,033 \\
Insulin & $184,92 \pm 61,85$ & $126,07 \pm 38,82$ & $58,86 \pm 19,29$ & 0,009 \\
OAD + Insulin & $224,83 \pm 59,88$ & $132,00 \pm 23,62$ & $92,83 \pm 26,99$ & 0,018 \\
\hline
\end{tabular}

Tabe1 4. Perubahan Rata-rata HbA1c Pasien DM tipe 2 Komplikasi RD

\begin{tabular}{lllcc}
\hline Jenis Obat & $\begin{array}{l}\text { Rata-rata } \\
\text { KGDP Pre } \\
(\mathbf{m g} / \mathbf{d L})\end{array}$ & $\begin{array}{l}\text { Rata-rata } \\
\text { KGDP Post } \\
\mathbf{( m g} / \mathbf{d L})\end{array}$ & $\begin{array}{c}\text { Selisih } \\
\mathbf{( m g} / \mathbf{d L})\end{array}$ & $\mathbf{P}$ \\
\hline OAD & $189,44 \pm 49,46$ & $137,22 \pm 49,31$ & $52,22 \pm 20,34$ & 0,033 \\
Insulin & $184,92 \pm 61,85$ & $126,07 \pm 38,82$ & $58,86 \pm 19,29$ & 0,009 \\
OAD + Insulin & $224,83 \pm 59,88$ & $132,00 \pm 23,62$ & $92,83 \pm 26,99$ & 0,018 \\
\hline
\end{tabular}

Tabe1 5. Perubahan Derajat RD pada Pasien DM tipe 2 Komplikasi RD

\begin{tabular}{|c|c|c|c|c|c|}
\hline \multirow{2}{*}{ Derajat RD } & \multicolumn{3}{|c|}{ Jenis Obat } & \multirow{2}{*}{ Jumlah Total } & \multirow{2}{*}{ Persentase } \\
\hline & OAD & Insulin & OAD+Insulin & & \\
\hline $\begin{array}{l}\text { Terjadi peningkatan } \\
\text { derajat RD }\end{array}$ & 1 & 4 & 0 & 5 & $17,24 \%$ \\
\hline $\begin{array}{ll}\text { Tidak } & \text { terjadi } \\
\text { peningkatan } & \text { derajat } \\
\text { RD } & \end{array}$ & 8 & 10 & 6 & 24 & $82,76 \%$ \\
\hline
\end{tabular}


DOI: https://doi.org/10.24843/JFU.2019.v08.i01.p08

pISSN: 2301-7716; eISSN: 2622-4607

Jurnal Farmasi Udayana, Vol 8, No 1, Tahun 2019, 50-58

\section{PEMBAHASAN}

\section{Karakteristik Subjek Penelitian}

Data pada tabel 1 jenis kelamin laki-laki lebih banyak ditemukan dibandingkan dengan perempuan yaitu sebanyak 18 pasien $(62,1 \%)$. Penelitian yang dilakukan oleh Hussain dkk. (2015) menunjukkan jenis kelamin laki-laki merupakan faktor resiko RD sehingga distribusi jenis kelamin didominasi oleh lakilaki. Penelitian oleh Raman (2014) menunjukkan jenis kelamin laki-laki merupakan faktor resiko RD karena lebih banyak dipengaruhi oleh gaya hidup seperti kebiasaan merokok, minum alkohol, dan minum soda yang seringkali meningkatkan progresivitas RD.

Berdasarkan karakteristik usia diketahui bahwa proporsi paling tinggi berada pada kelompok usia 56-65 tahun sebanyak 11 pasien $(37,3 \%)$, selanjutnya pada kelompok usia 46-55 tahun sebanyak 9 pasien (31,0\%),pada usia >65 tahun sebanyak 6 pasien $(20,7 \%)$ dan kelompok usia dengan proposi paling rendah yaitu 36-45 tahun sebanyak 3 pasien $(10,3 \%)$. Penelitian yang dilakukan oleh Virgayanti (2012) di Rumah Sakit Umum Pusat H. Adam Malik Medan menunjukan penderita $\mathrm{RD}$ pada pasien $\mathrm{DM}$ terbanyak berada pada kelompok usia 51-70 tahun yakni sebesar 65,91\% (Virgayanti, 2012). Faktor risiko penting terjadinya RD adalah usia. Beberapa penelitian melaporkan prevalensi RD mengalami peningkatan dengan bertambahnya usia (Hussain dkk, 2013: Sulaiman dkk, 2010). Bertambahnya usia dapat menurunkan fungsi tubuh yang disebakan oleh proses apoptosis sel yang dimulai dari usia lebih dari 45 tahun. Keadaan hiperglikemi kronis, reaksi inflamasi, dan stress oksidatif dapat mempercepat terjadinya apoptosis sel di retina sehingga mengakibatkan terjadinya keadaan retinopati. Hal tersebut menjelaskan kejadian RD pada pasien DM ditemukan meningkat seiring bertambahnya usia (Kowluru dan Menon, 2012).
Berdasarkan lama menderita DM dapat dilihat bahwa lama menderita DM pada pasien DM tipe 2 komplikasi RD terbanyak berada pada rentang 5-10 tahun (72,4\%). Lama menderita DM dikaitan dengan paparan hiperglikemi dalam waktu lama dapat menyebabkan perubahan biokimiawi dan fisiologi berupa perubahan seluler pada membran basalis retina sehingga terjadi kerusakan pada pembuluh darah kapiler retina berupa hilangnya sel perisit, proliferasi sel endotel dan penebalan membran basal yang mengakibatkan oklusi kapiler dan nonperfusi pada retina. Oklusi kapiler akan menyebakan pendarahan dan timbulnya pembuluh darah baru yang rapuh sehingga bisa menyebabkan pendarahan berulang yang menurunkan tajam pengelihatan (Suryathi dkk., 2015).

\section{Perubahan Rata-rata KGDP}

Hasil penelitian pada tabel 2 menunjukan bahwa terdapat penurunan ratarata KGDP yang signifikan $(\mathrm{p}<0,05)$ selama enam bulan terapi pada ketiga kelompok terapi, baik kelompok OAD, insulin maupun kombinasi OAD + insulin. Rata-rata KGDP pada pasien yang mendapat terapi OAD, insulin dan kombinasi OAD + Insulin mengalami penurunan yang signifikan $(\mathrm{p}<0,05)$ dengan selisih berturu-turut sebesar $52,22 \pm 20,34 \mathrm{mg} / \mathrm{dL}$ (dari 189,44 $\pm 49,46$ menjadi $137,22 \pm 49,31 \mathrm{mg} / \mathrm{dL}), 58,86 \pm 19,29$ $\mathrm{mg} / \mathrm{dL}$ (drai 184,92 $\pm 61,85$ menjadi $126,07 \pm 38,82 \mathrm{mg} / \mathrm{dL}), 92,83 \pm 26,99 \mathrm{mg} / \mathrm{dL}$

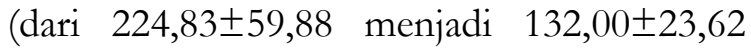
$\mathrm{mg} / \mathrm{dL}$ ). Penelitian Pasquel et al. (2015) yang menyatakan bahwa rejimen pengobatan DM, baik OAD maupun insulin mampu menghasilkan kontrol glikemik yang cepat dan berkelanjutan tanpa perbedaan yang signifikan antara pasien yang diobati dengan insulin atau dengan OAD, sehingga kedua rejimen pengobatan ini mampu menurunkan KGDP secara singnifikan pada pasien DM tipe 2 komplikasi RD. 
DOI: https://doi.org/10.24843/JFU.2019.v08.i01.p08

pISSN: 2301-7716; eISSN: 2622-4607

Jurnal Farmasi Udayana, Vol 8, No 1, Tahun 2019, 50-58

Penurunan KGDP pada kelompok yang mendapat terapi kombinasi OAD + insulin terlihat paling besar diantara terapi lannya. Hal ini didukung oleh hasil penelitian Echtay et al., (2017) yang menunjukan ratarata KGDP pasien mengalami penurunan yang signifikan dari $213,7 \pm 60,1 \mathrm{mg} / \mathrm{dL}$ menjadi 120,3 $\pm 25,7 \mathrm{mg} / \mathrm{dL} \quad(\mathrm{p}<0,0001)$. Penggunaan insulin yang dikombinasikan dengan OAD pada pasien DM tipe 2 dikatakan dapat meningkatkan kontrol glikemik pasien tanpa adanya peningkatan kejadian hipoglikemi dan peningkatan berat badan pada pasien. Hal tersebut sejalan dengan temuan dalam penelitian ini yang menunjukan penurunan KGDP pada penggunaan kombinasi OAD + insulin yang cukup besar yaitu 92,83 $\pm 26,99 \mathrm{mg} / \mathrm{dL}$.

\section{Perubahan Rata-rata KGD2PP}

Hasil penelitian pada tabel 3 menunjukan rata-rata KGD2PP pada pasien yang mendapat terapi OAD dan insulin menurun signifikan $(\mathrm{p}<0,05)$ masing-masing

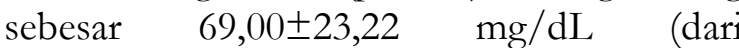
$234,11 \pm 83,87$ menjadi $165,11 \pm 43,13 \mathrm{mg} / \mathrm{dL})$

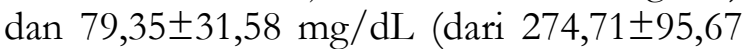

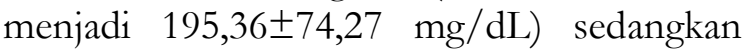
pada terapi OAD + insulin belum menunjukan penurunan yang signifikan $(\mathrm{p}>0,05)$ yaitu sebesar $67,33 \pm 49,55 \mathrm{md} / \mathrm{dL}$

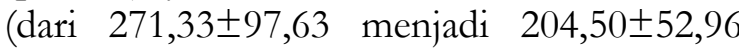
$\mathrm{mg} / \mathrm{dL})$.

Penurunan KGD2PP tertinggi terlihat pada penggunaan terapi insulin yaitu sebesar $79,35 \pm 31,58 \mathrm{mg} / \mathrm{dL}$. Insulin yang digunakan pasien dalam penelitian ini adalah kombinasi insulin long acting dengan rapid acting. Secara fisiologis, kebutuhan insulin pada pasien DM terdiri atas insulin basal dan insulin prandial. Insulin prandial adalah jumlah insulin yang dibutuhkan untuk mengkonversi bahan nutrient ke dalam bentuk energi cadangan sehingga tidak terjadi hiperglikemi setelah makan. Kebutuhan insulin prandial pada pasien DM tipe 2 dapat dipenuhi dengan penggunaan insulin short acting dan rapid acting
(Rismayanthi, 2010). Menurut Slattery et al., (2017) penggunaan rapid acting insulin 15-20 menit sebelum makan dapat memberikan kontrol glukosa darah post prandial yang optimal hingga mampu menurunkan kadar glukosa darah post prandial sebesar $30 \%$.

\section{Perubahan Rata-rata HbA1c}

Hasil penelitian pada tabel 4 menunjukan rata-rata $\mathrm{HbA1c}$ mengalami penurunan yang signifikan $(\mathrm{p}<0,05)$ pada pasien yang mendapat terapi $\mathrm{OAD}$, insulin dan kombinasi OAD + insulin masing-

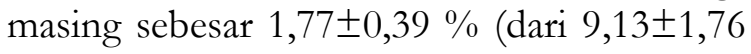
menjadi 7,36 $\pm 0,91 \%$ ), 1,58 $\pm 0,52 \%$ (dari $9,00 \pm 2,20$ menjadi $7,41 \pm 0,99 \%$ dan $1,60 \pm 0,55 \%$. (drai 9,05 $\pm 2,37$ menjadi $7,73 \pm 1,16 \%$ ). Pada penggunaan OAD, kadar HbA1c pasien terlihat mengalami penurunan yang cukup besar diantara terapi lainnya yaitu

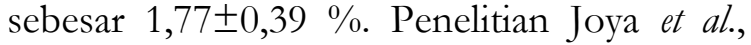
(2011) menemukan bahwa penggunaan OAD selama 6 bulan terapi pada pasien DM menurunkan kadar HbA1c dari 10,3 \% menjadi 6,4\%. Menurut Moon et al., (2017) pengunaan obat antidiabetes oral efektif ketika dalam bentuk kombinasi dengan metformin. Penggunaan antidiabetes oral dengan mekanisme aksi yang saling melengkapi misalnya pada kombinasi sulfonilurea + metformin terbukti efektif dalam mencapai kontrol glikemik. Metformin menurunkan darah kadar glukosa dengan menghambat produksi glukosa hati dan dengan meningkatkan sensitifitas jaringan perifer terhadap insulin sebaliknya sulfonilurea seperti glimepirid dan gliklazid menurunkan glukosa darah dengan meningkatkan sekresi insulin (Hassan dan Abd-Allah, 2015).

\section{Perubahan Derajat Retinopati Diabetik}

Hasil observasi selama 6 bulan (pre dan post terapi) pasien DM tipe 2 komplikasi RD selama 6 bulan terapi dapat dilihat pada tabel 5. Hasil penelitian menunjukan perubahan derajat RD terjadi pada 5 dari $29(17,24 \%)$ pasien. Peningkatan derajat RD yang terjadi 
DOI: https://doi.org/10.24843/JFU.2019.v08.i01.p08

pISSN: 2301-7716; eISSN: 2622-4607

Jurnal Farmasi Udayana, Vol 8, No 1, Tahun 2019, 50-58

terdiri atas 1 pasien mengalami peningkatan derajat RD dari Okuli Dextra Sinistra (ODS) Moderate NPDR ke ODS Severe NPDR, 1 pasien mengalami peningkatan derajat $\mathrm{RD}$ dari Okuli Dextra (OD) Early PDR ke OD High Risk PDR (pada mata kiri pasien), 1 pasien mengalami peningkatan derajat $\mathrm{RD}$ dari ODS Severe NPDR ke ODS Early PDR, 1 pasien mengalami peningkatan derajat $\mathrm{RD}$ dari ODS Severe NPDR ke ODS High Risk PDR dan 1 pasien mengalami peningkatan derajat RD dari OD Early PDR ke OD High Risk PDR.

Kadar glukosa darah merupakan salah satu faktor eksternal dari RD. Kontrol glukosa darah merupakan salah satu faktor yang meningkatkan perkembangan $\mathrm{RD}$, sedangkan kontrol glukosa darah yang baik dengan kadar HbA1c $<7 \%$ dapat menurunkan progresifitas komplikasi yang terjadi (Kemenkes RI, 2014; Refa dan Dewi, 2015). Apabila dikaitkan dengan nilai HbA1c pasien dalam penelitian ini, semua pasien yang mengalami peningkatan derajat RD memiliki kadar HbA1c $>7 \%$ masing-masing sebesar 8,$7 ; 9,5 ; 7,4 ; 8,1 ; 9,2 \%$. Hal ini dapat menjadi salah satu faktor yang menyebabkan meningkatnya derajat RD yang dialami pasien tersebut.

Apabila dikaitkan dengan jenis terapi yang diterima pasien yang mengalami kenaikan derajat $\mathrm{RD}$, sebanyak 4 pasien mendapat terapi insulin (kombinasi long acting insulin dan rapid acting insulin) dan 1 pasien mendapat terapi OAD (kombinasi acarbose dan sulfonilurea). Berdasarkan studi yang dilakukan oleh Meng et al., (2012) menunjukkan bahwa insulin berinteraksi dengan NADPH subunit 4 (Nox-4) menyebabkan terjadinya produksi berlebih dari Reactive Oxygen Species (ROS) yang kemudian dapat memicu terjadinya stres oksidatif dalam sel endotel retina. Reactive Oxygen Species yang diproduksi terlibat dalam aktivasi HIF- $1 \alpha$ yang pada akhirnya mengarah pada ekspresi VEGF. Vascular
Endothelial Growth Factor dapat memediasi terjadinya angiogenesis dan neovaskularisasi. Proses angiogenesis merupakan sebuah proses pembentukan pembuluh darah baru yang khas dengan perkembangan $\mathrm{RD}$ ke derajat yang lebih parah. Onset dan memburuknya RD diduga dihasilkan dari pensinyalan ROS dan aktivasi HIF- $1 \alpha$ yang berakibat pada ekspresi VEGF.

Pada penelitian yang dilakukan oleh $\mathrm{Li}$ et al., (2018) dikatakan penggunaan OAD khususnya golongan bigunid yaitu metformin memiliki efek yang menguntungkan dalam mencegah perkembangan RD karena aktivitas anti-inflamasi dan antiangiogenik yang dimiliki metformin. Jalur inflamasi dan angiogenesis dianggap mendasari perkembangan RD. Temuan tersebut sejalan dengan hasil penelitian ini dimana pada penggunaan metformin tidak ditemukan peningkatan derajat RD pada pasien. Studi invivo yang dilakukan oleh Yi et al. (2016) menemukan bahwa penggunaan metformin dapat mengurangi progresivitas $\mathrm{RD}$ dengan menekan terjadinya neovaskularisasi retina. Penggunaan metformin menurunkan fosforilasi VEGFR2 (Vascular Endothelial Growth Factor Receptor 2) sehingga menghambat pensinyalan VEGF.

\section{KESIMPULAN}

Rata-rata KGDP dan HbA1c pasien mengalami penurunan yang signifikan $(p<0,05)$ pada penggunaan OAD, insulin dan kombinasi OAD + insulin. Rata-rata KGD2PP pasien mengalami menurun yang signifikan pada penggunaan OAD dan insulin $(\mathrm{p}<0,05)$, namun pada penggunaan kombinasi OAD + insulin belum menunjukan penurunan yang signifikan $(p>0,05)$. Peningkatan derajat $R D$ terjadi pada 5 dari 29 pasien $(17,24 \%)$.

\section{UCAPAN TERIMAKASIH}

Terimakasih kepada Tuhan Yang Maha Esa atas berkat rahmat-Nya penulis dapat menyelesaikan penelitian ini, serta kepada 
DOI: https://doi.org/10.24843/JFU.2019.v08.i01.p08

pISSN: 2301-7716; eISSN: 2622-4607

Jurnal Farmasi Udayana, Vol 8, No 1, Tahun 2019, 50-58

dosen pembimbing, pihak RSUP Sanglah Denpasar, serta pihak lainnya yang turut membantu peneliti dalam melaksanakan penelitian ini.

\section{DAFTAR PUSTAKA}

American Academy of Opbtalfmology (AAO). 2014, Preferred Practice Pattern Guidelines: Diabetic Retinopathy, American Academy of Ophtalfmolog, San Fransisco.

Echtay, A., Andari, E., Atallah, P., Moufarrege., Nemr, R. 2017. Insulin Detemir in Combination with Oral Antidiabetic Drugs Improves Glycemic Control in Persons with Type 2 Diabetes in Near East Countries: Results from The Lebanese Subgroup, Ethnicity \& Disease, 27:45-54.

Hassan, M dan Abd-Allah, G.M. 2015. Effects of Metformin Plus Gliclazide versus Metformin Plus Glimepiride On Cardiovascular Risk Factors in Patients with Type 2 Diabetes Mellitus, Pak. J. Pharm. Sci, 28:1723-1730.

Hussain, S., Rashad, M.Q., Arshad, M.I., Ahmed, A, Ullah, E. 2013, Risk Factors of Retinopathy in Type 2 Diabetes Mellitus at A Tertiary Care Hospital Bahawalpur Pakistan, Pak J Med Sci, 29:536-539.

Joya, G.J., Fernandez, M., Cervera, A., Reyna, S., Ghosh, S., Triplitt, C., et al. 2011, Effects of Insulin and Oral Antidiabetic Agents on Glucose Metabolism, Vascular Dysfunction and Skeletal Muscle Inflammation in Type 2 Diabetic Subject. Diabetes Metab Res Rev, 27:373-382.
Kementrian Kesehatan RI. 2014, Situasi dan Analisis Diabetes, Pusat Data dan Informasi Kementrian Kesehtan RI, Jakarta.

Kowluru, R.A., Menon, B., Gierhart, J. 2010. Metabolic

Abnormalities in Diabetic Patients.

Investigative Ophthalmol and Visual Science Journal 49:164-171.

Lee, R., Wong, T.Y., Sabanayagam, C. 2015, Epidemiology of Diabetic Retinopathy, Diabetic Macular Edema and Related Vision Loss, Eye and Vision, 2:1-25.

Li, Y., Ryu, C., Munie, M., Noorulla, S., Rana, S., Paul., et al. 2018. Association of Metformin Treatment with Reduced Severity of Diabetic Retinopathy in Type 2 Diabetic Patients, Journal of Diabetes Research 1:1-8.

Meng, D., Mei, A., Liu, A., Kang, X., Shi, X., Qian, R., Chen, R. 2012. NADPH Oxidase 4 Mediates Insulin-Stimulated HIF- $1 \alpha$ and VEGF Expression, and Angiogenesis in Vitro, PLoS One, 7:1-9.

Moon, M.K., Hur, K.Y., Ko, S., Park, S., Lee, B., Kim, J.H., et al. 2017, Combination Therapy of Oral Hypoglycemic Agents in Patients with Type 2 Diabetes Mellitus, The Korean Journal of Internal Medicine, 32:976-983.

Nasution, K. 2011, Deteksi Dini Retinopati Diabetik, Journal of Indonesian Medical Association, 61:307-309.

Pasquel, F.J., Powell, W., Peng, Johnson, T.M., Sadeghi-Yarandi, S., Newton, C., Smiley, D., Toyoshima, M.T., Aram, P., Umpierrez, G.E. 2015. A Randomized Controlled Trial Comparing Treatment 
Sukarmini dkk.

DOI: https://doi.org/10.24843/JFU.2019.v08.i01.p08

pISSN: 2301-7716; eISSN: 2622-4607

Jurnal Farmasi Udayana, Vol 8, No 1, Tahun 2019, 50-58

with Oral Agents and Basal Insulin In Elderly Patients With Type 2 Diabetes In Long-Term Care Facilitie, BMJ Open Diabetes Research and Care, 3:1-6.

PERKENI. 2015, Konsensus Pengelolaan dan Pencegahan Diabetes Melitus Tipe $2 \mathrm{Di}$ Indonesia Tahun 2015, Pengurus Besar Perkumpulan Endokrinologi Indonesia, Jakarta.

Raman, R. 2014, Prevalence and Risk Factors for Diabetic Retinopathy in Rural India, BMJ Open Diabetes Research and Care, 2:1-9.

Rismayanthi, C. 2010. Terapi Insulin sebagai Alternatif Pengobatan bagi Penderita Diabetes, Medikora, 6:29-36.

Sitompul R. 2011, Retinopati diabetik. Indonesian Medical Association Journal, 61: 337-341.

Slattery, D., Arniel, S.A., Choudhary, P. 2017, Optimal Prandial Timing of Bolus Insulin in Diabetes Management: A Review, Diabetic Medicine, 35:306-316.

Soegondo, S. 2008, Hidup Sehat Secara Mandiri dengan Diabetes Melitus, Kencing Manis, Sakit Gula, Fakultas Kedokteran Universitas Indonesia, Jakarta.

Sulaiman, M.S., Suhaiza, N.S., Mukthar, A.N., Ismail, J.S. 2010, Glicemic Control Among Type II Diabetes Patients in Kelatan, NCD Malaysia, 3:15-23.

Suryathi, N.M.A., Budhiastra, I.P., Jayanegara, I.W.G., Widiana, I.G. 2015. Kejadian Retinopati Diabetik Pada
Pasien Diabetes Mellitus, Medicina, 46:86-91

Tschöpe, D., Hanefeld, M., Meier, J.J., Gitt, A.K., Halle, M., Bramlage, P., Schumm-Draeger, P.M. 2013, The Role Of Co-Morbidity in The Selection of Antidiabetic Pharmacotherapy in Type-2 Diabetes, Cardiovascular Diabetology, 12:1-10.

Virgayanti, V. 2012, 'Prevalensi Retinopati Diabetik Pada Penderita Diabetes Melitus di RSUP H. Adam Malik Medan', Tesis, M.K.K, Uuniversitas Sumatera Utara, Medan

World Health Organization (WHO). 2016, Global Report on Diabetes, World Health Organization, France.

Yau, J.W.Y., Rogers, S. L., Kawasaki, R., Lamourex, E.L., Kowalski, J.W., Bek, T., et al. 2012, Global Prevalence and Major Risk Factors of Diabetic Retinopathy, Diabetes Care. 35:556-564.

Yi, Q.Y., Deng, G., Chen, N., Bai, Z., Yuan, Z., Wu, G.H., Wang, Y. Wu, S. 2016. Metformin Inhibits Development of Diabetic Retinopathy Through Inducing Alternative Splicing of VEGF-A, Am J Transl Res, 8:39473954.

Zhang, X., Zhao, J., Zhao, T., Liu, H. 2015, Effects of Intensive Glycemic Control in Ocular Complications in Patients with Type 2 Diabetes: A Meta-Analysis of Randomized Clinical Trials, Endocrine, 49:78-79. 